\title{
CrystEngComm
}

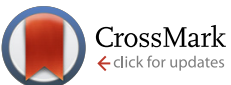

Cite this: CrystEngComm, 2014, 16, 11064

\section{1,2,4,5-Benzenetetrasulfonic acid and 1,4-benzenedisulfonic acid as sulfo analogues of pyromellitic and terephthalic acids for building coordination polymers of manganese $\dagger$}

\author{
Christina Zitzer, ${ }^{a}$ Thomas W. T. Muesmann, ${ }^{a}$ Jens Christoffers, ${ }^{a}$ \\ Christian Schwickert, ${ }^{\mathrm{b}}$ Rainer Pöttgen ${ }^{\mathrm{b}}$ and Mathias S. Wickleder ${ }^{\star a}$
}

\begin{abstract}
The new polysulfonic acids $\mathrm{H}_{4} \mathrm{~B} 4 \mathrm{~S}$ (1,2,4,5-benzenetetrasulfonic acid) and $\mathrm{H}_{2} \mathrm{BDS}$ (1,4-benzenedisulfonic acid) were used for the preparation of five manganese coordination polymers. The reactions of $\mathrm{H}_{4} \mathrm{~B} 4 \mathrm{~S}$ and $\mathrm{MnCO}_{3}$ were performed in dimethylformamide (DMF) or $\mathrm{N}$-methylpyrrolidone (NMP) as solvent in sealed glass ampoules at elevated temperatures. Two benzenetetrasulfonates could be obtained, $\left[\mathrm{NH}_{2}\left(\mathrm{CH}_{3}\right)_{2}\right]_{2}\left\{\mathrm{Mn}(\mathrm{B} 4 \mathrm{~S})(\mathrm{DMF})_{2}\right\}$ (I) $\left(P 2_{1} / c, Z=2, a=942.02(5) \mathrm{pm}, b=1684.86(6) \mathrm{pm}, c=918.45(5) \mathrm{pm}\right.$, $\left.\beta=97.746(6)^{\circ}, R_{1} ; \mathrm{W} R_{2}\left(I_{\circ}>2 \sigma\left(I_{\circ}\right)\right)=0.0357 ; 0.0771\right)$ and $[\mathrm{HNMP}]_{2}\left\{\mathrm{Mn}(\mathrm{B} 4 \mathrm{~S})(\mathrm{NMP})_{2}\right\}$ (II) $\left(P 2_{1} / c, Z=2\right.$, $a=931.7(1) \mathrm{pm}, b=1049.2(1) \mathrm{pm}, c=1944.9(1) \mathrm{pm}, \beta=113.529(3)^{\circ}, R_{1} ; \mathrm{w} R_{2}\left(I_{\circ}>2 \sigma\left(I_{\circ}\right)\right)=0.0470$; 0.0952). Both compounds exhibit anionic chains according to ${ }_{\infty}^{1}\left\{\mathrm{Mn}(\mathrm{B} 4 \mathrm{~S})_{2 / 2}(\mathrm{~L})_{2}\right\}^{2-}(\mathrm{L}=\mathrm{DMF}, \mathrm{NMP})$. The $\mathrm{Mn}^{2+}$ ions are in octahedral coordination of oxygen atoms. The charge of the anionic chains is either compensated by dimethylammonium cations, $\left[\mathrm{NH}_{2}\left(\mathrm{CH}_{3}\right)_{2}{ }^{+}\right]$, or by protonated NMP molecules, HNMP . Solvothermal reactions of $\mathrm{H}_{2} \mathrm{BDS}$ and $\mathrm{MnCO}_{3}$ in the solvents $\mathrm{DMF}, \mathrm{NMP}$ and dimethylacetamide (DMA), respectively, yielded the disulfonates $\mathrm{Mn}(\mathrm{BDS})(\mathrm{DMF})_{2}$ (III) $(P \overline{1}, Z=1, a=514.3(1) \mathrm{pm}, b=926.2(1) \mathrm{pm}$, $\left.C=940.2(1) \mathrm{pm}, \alpha=93.552(8)^{\circ}, \beta=99.993(7)^{\circ}, \gamma=99.237(7)^{\circ}, R_{1} ; w R_{2}\left(I_{\circ}>2 \sigma\left(I_{\circ}\right)\right)=0.0290 ; 0.0637\right)$, $\mathrm{Mn}(\mathrm{BDS})(\mathrm{DMA})_{2}(\mathrm{IV})\left(P \overline{1}, Z=2, a=936.00(4) \mathrm{pm}, b=984.94(4) \mathrm{pm}, c=1034.75(5) \mathrm{pm}, \alpha=81.606(2)^{\circ}\right.$, $\left.\beta=88.941(2)^{\circ}, \gamma=82.364(2)^{\circ}, R_{1} ; \mathrm{W} R_{2}\left(I_{\circ}>2 \sigma\left(I_{0}\right)\right)=0.0387 ; 0.1046\right)$ and $\mathrm{Mn}(\mathrm{BDS})(\mathrm{NMP})_{2}(\mathrm{~V})(P \overline{1}, Z=2$, $a=962.97(3) \mathrm{pm}, b=976.76(3) \mathrm{pm}, c=1034.23(3) \mathrm{pm}, \alpha=89.371(1)^{\circ}, \beta=78.839(1)^{\circ}, \gamma=87.604(2)^{\circ}$, $\left.R_{1} ; \mathrm{W} R_{2}\left(I_{0}>2 \sigma\left(I_{0}\right)\right)=0.0243 ; 0.0713\right)$. In the crystal structures of the three compounds, the octahedrally coordinated $\mathrm{Mn}^{2+}$ ions are linked by the disulfonate ions to layers according to ${ }_{\infty}^{2}\left\{\mathrm{Mn}(\mathrm{BDS})_{4 / 4}(\mathrm{~L})_{2}\right\}$ $(\mathrm{L}=\mathrm{DMF}, \mathrm{DMA}, \mathrm{NMP})$. The thermal analysis of all compounds shows that they can be desolvated completely and that the remaining solvent-free sulfonates exhibit decomposition temperatures up to $500{ }^{\circ} \mathrm{C}$ that is exceptionally high when compared to the respective carboxylates. Temperature-dependent magnetic susceptibility measurements of $\left[\mathrm{NH}_{2}\left(\mathrm{CH}_{3}\right)_{2}\right]_{2}\left\{\mathrm{Mn}(\mathrm{B} 4 \mathrm{~S})(\mathrm{DMF})_{2}\right\}$ show paramagnetic behavior of the $\mathrm{Mn}^{2+}$ ions.
\end{abstract}

Received 4th August 2014,

Accepted 15th October 2014

DOI: $10.1039 / c 4 c e 01618 a$

www.rsc.org/crystengcomm open pores are referred to as metal-organic frameworks (MOFs). ${ }^{3}$ By the choice of the metal that is used for building CPs and MOFs, specific properties can be implemented. For example, rare earth metals may lead to interesting luminescence properties, ${ }^{4,5}$ while transition metals like Mn, Fe, Co and Ni can cause paramagnetism or even cooperative magnetic phenomena. ${ }^{5-7}$ The dimensionality and the porosity of CPs and MOFs can be tuned by the choice of the polydentate ligands, the so-called linkers. ${ }^{8-10}$ The majority of used linkers are polycarboxylate anions and neutral nitrogen-containing heterocycles. One of the reasons for the extensive use of polycarboxylates is that the respective polycarboxylic acids are commercially available in a great variety or that they can at least be prepared very easily. Unfortunately, this is not the case for the sulfo analogues of these acids, the so-called 
polysulfonic acids. Only a limited number of these acids are available and most of the compounds are even lacking reliable synthesis protocols. On the other hand, it has been shown that polysulfonate anions are interesting linkers because they show different coordination chemistry compared to carboxylates. For example, polysulfonates are weaker ligands making them good candidates for the formation of very flexible host structures. This has been intensively studied for those polysulfonic acids which are available up to now. ${ }^{11,12}$ However, it remains a problem that a lot of potentially interesting polysulfonic acids were not accessible. This was especially true for the analogues of very simple and widely used polycarboxylic acids like 1,4-benzenedicarboxylic acid ("terephthalic acid"), 1,3,5-benzenetricarboxylic acid ("trimesic acid"), 1,2,4,5-benzenetetrasulfonic acid ("pyromellitic acid"), and 1,2,3,4,5,6-benzenehexasulfonic acid ("mellitic acid"). Thus, some years ago, we initiated a research program aiming at the development of simple and scalable preparation routes for polysulfonic acids and their use for the preparation of new CPs and MOFs. In the course of these investigations, we were also able to prepare the sulfo analogues of the abovementioned carboxylic acids (Fig. 1) ${ }^{13-15}$ It turned out that the metal salts of these acids usually show low-dimensional structures (1D and 2D) with the metals additionally coordinated by solvent molecules. In all cases, however, the solvent can be removed by heating without decomposition of the organic linker. In some cases, the desolvated compounds are thermally stable up to $600{ }^{\circ} \mathrm{C}$ that is remarkably high, especially when compared to the respective carboxylates. This is of special interest if temperature sensible functions of the desolvated compounds like gas storage are envisioned. As a further result of our ongoing research, we here present the new manganese compounds of 1,4-benzenedisulfonic acid $\left(\mathrm{H}_{2} \mathrm{BDS}, 1\right)$ and 1,2,4,5-benzenetetrasulfonic acid $\left(\mathrm{H}_{4} \mathrm{~B} 4 \mathrm{~S}, 2\right)$.

\section{Experimental section}

\section{Preparation of compounds}

General. The reactions were carried out in thick-walled glass ampoules (length: $300 \mathrm{~mm}$, diameter: $16 \mathrm{~mm}$ ). The
$1 \mathrm{H}_{2} \mathrm{BDS}$<smiles>O=S(=O)(O)c1cc(S(=O)(=O)O)c(S(=O)(=O)O)cc1S(=O)(=O)O</smiles>

$2 \mathrm{H}_{4} \mathrm{~B} 4 \mathrm{~S}$

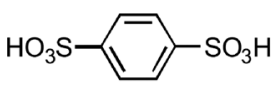<smiles>O=S(=O)(O)c1cc(S(=O)(=O)O)cc(S(=O)(=O)O)c1</smiles>

$3 \mathrm{H}_{3} \mathrm{BTS}$<smiles>O=S(=O)(O)c1c(S(=O)(=O)O)c(S(=O)(=O)O)c(S(=O)(=O)O)c(S(=O)(=O)O)c1S(=O)(=O)O</smiles>

$4 \mathrm{H}_{6} \mathrm{BHS}$
Fig. 1 Selected polysulfonic acids which have been prepared in our groups as sulfo analogues of well-known polycarboxylic acids. The manganese salts of 1 and $\mathbf{2}$ are presented in this work. ampoules were loaded with the reactants, torch-sealed under vacuum, and placed in a resistance furnace. The ampoules are heated up to $105{ }^{\circ} \mathrm{C}$ within $6 \mathrm{~h}$, held for $24 \mathrm{~h}$ and cooled down to room temperature within $96 \mathrm{~h}$. The products were obtained as colorless crystals which were separated from the supernatant by decantation. $\left[\mathrm{NH}_{2}\left(\mathrm{CH}_{3}\right)_{2}\right]_{2}\left\{\mathrm{Mn}(\mathrm{B} 4 \mathrm{~S})(\mathrm{DMF})_{2}\right\}$ : $20 \mathrm{mg}(0.043 \mathrm{mmol})$ of $\mathrm{H}_{4} \mathrm{~B} 4 \mathrm{~S}, 14 \mathrm{mg}(0.122 \mathrm{mmol})$ of $\mathrm{MnCO}_{3}$, and $3 \mathrm{ml}$ of DMF. [HNMP $]_{2}\left\{\mathrm{Mn}(\mathrm{B} 4 \mathrm{~S})(\mathrm{NMP})_{2}\right\}: 20 \mathrm{mg}$ $(0.043 \mathrm{mmol})$ of $\mathrm{H}_{4} \mathrm{~B} 4 \mathrm{~S}, 5 \mathrm{mg}(0.043 \mathrm{mmol})$ of $\mathrm{MnCO}_{3}$, and $3 \mathrm{ml}$ of NMP. $\mathrm{Mn}(\mathrm{BDS})(\mathrm{DMF})_{2}: 20 \mathrm{mg}(0.073 \mathrm{mmol})$ of $\mathrm{H}_{2} \mathrm{BDS}, 17 \mathrm{mg}(0.148 \mathrm{mmol})$ of $\mathrm{MnCO}_{3}$, and $3 \mathrm{ml}$ of DMF. $\mathrm{Mn}(\mathrm{BDS})(\mathrm{DMA})_{2}: 20 \mathrm{mg}(0.073 \mathrm{mmol})$ of $\mathrm{H}_{2} \mathrm{BDS}, 8 \mathrm{mg}$ $(0.070 \mathrm{mmol})$ of $\mathrm{MnCO}_{3}$, and $3 \mathrm{ml}$ of DMA. $\mathrm{Mn}(\mathrm{BDS})(\mathrm{NMP})_{2}$ : $20 \mathrm{mg}(0.073 \mathrm{mmol})$ of $\mathrm{H}_{2} \mathrm{BDS}, 17 \mathrm{mg}(0.148 \mathrm{mmol})$ of $\mathrm{MnCO}_{3}$, and $3 \mathrm{ml}$ of NMP. The acids $\mathrm{H}_{2} \mathrm{BDS}$ and $\mathrm{H}_{4} \mathrm{~B} 4 \mathrm{~S}$ were prepared as previously described. ${ }^{13-15} \mathrm{MnCO}_{3}$ turned out to be the best starting product, while the use of manganese acetate or nitrate usually leads to undesired by-products (solvates of the salts). However, even under different reaction conditions, the product usually contains traces of $\mathrm{MnCO}_{3}$ that is not seen in XRD but in magnetochemistry.

\section{IR spectroscopy}

IR data were collected with a Bruker Tensor 27 spectrometer using the attenuated total reflection (ATR) method on some dried single crystals. The specimen was prepared and placed onto the detector head in a glove box and transferred to the spectrometer under inert atmosphere. The IR data were processed with the OPUS 6.5 program. ${ }^{16}$

$\left[\mathbf{N H}_{2}\left(\mathbf{C H}_{3}\right)_{2}\right]_{2}\left\{\mathbf{M n}(\mathrm{B} 4 \mathrm{~S})(\mathrm{DMF})_{2}\right\} . \quad \operatorname{IR}(\mathrm{ATR}): 3471 \quad(\mathrm{w})$, $3118(\mathrm{~m}), 2807(\mathrm{w}), 2451(\mathrm{w}), 1651$ (s), 1614 (m), 1465 (m), 1441 (m), 1376 (m), 1309 (w), 1274 (m), 1239 (s), 1183 (s), 1136 (s), 1109 (s), 1041 (s), 937 (m), 892 (m), 856 (m), 828 (m), $686(\mathrm{~s}), 669(\mathrm{~m}), 644(\mathrm{~s}), 573(\mathrm{~m}), 546(\mathrm{~s}) \mathrm{cm}^{-1}$. $[\mathrm{HNMP}]_{2}\left\{\mathrm{M}(\mathrm{B} 4 \mathrm{~S})(\mathrm{NMP})_{2}\right\}: 3548(\mathrm{~m}), 3461(\mathrm{w}), 3368(\mathrm{~m}), 3095$ (m), 1656 (s), 1518 (m), 1476 (m), 1459 (m), 1410 (m), 1311 (m), 1240 (s), 1177 (s), 1107 (s), 1045 (s), 1014 (s), 980 (m),

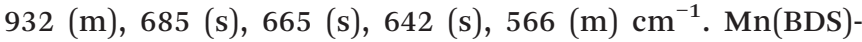
$(\mathrm{DMF})_{2}: 2992(\mathrm{w}), 2938$ (w), 2898 (w), 1652 (s), 1501 (w), 1440 (w), 1415 (m), 1389 (m), 1237 (s), 1184 (s), 1139 (s), 1109 (s), 1050 (s), 1011 (s), 870 (w), 846 (m), 685 (m), 664 (s), 579 (s), $570(\mathrm{~s}), 528(\mathrm{w}) \mathrm{cm}^{-1}$. Mn(BDS)(DMA) $23542(\mathrm{~m}), 3347(\mathrm{~m})$, 3221 (m), 3097 (w), 1633 (s), 1470 (w), 1393 (m), 1167 (s), 1128 (s), 1109 (s), 1035 (s), 998 (s), 833 (s), 663 (s), 564 (s), $531(\mathrm{w}) \mathrm{cm}^{-1}$. Mn(BDS)(NMP) $)_{2}: 3551(\mathrm{~m}), 3345(\mathrm{~m}), 3225(\mathrm{~m})$, 3097 (w), 1633 (m), 1394 (m), 1169 (s), 1131 (s), 1110 (s), 1042 (s), 1002 (s), 834 (s), 673 (s), 565 (s), 535 (m) cm².

\section{$\mathrm{X}$-ray structure determination}

Single crystals of the compounds $[\mathrm{HNMP}]_{2}\left\{\mathrm{Mn}(\mathrm{B} 4 \mathrm{~S})(\mathrm{NMP})_{2}\right\}$, $\mathrm{Mn}(\mathrm{BDS})(\mathrm{DMF})_{2}, \mathrm{Mn}(\mathrm{BDS})(\mathrm{DMA})_{2}$, and $\mathrm{Mn}(\mathrm{BDS})(\mathrm{NMP})_{2}$ were selected under protecting oil and transferred into the cold nitrogen stream $(120 \mathrm{~K})$ of a single-crystal diffractometer (BRUKER APEX II). The crystals of $\left[\mathrm{NH}_{2}\left(\mathrm{CH}_{3}\right)_{2}\right]_{2}\left\{\mathrm{Mn}(\mathrm{B} 4 \mathrm{~S})(\mathrm{DMF})_{2}\right\}$ are measured at $296 \mathrm{~K}$ on a single-crystal diffractometer 
(Stoe IPDS I). The collection of intensity data was performed at the abovementioned temperature for the respective best specimen. The structure solutions were successful by applying direct methods, and the structures were expanded by Fourier techniques. Refinement of the structures with introduction of anisotropic displacement parameters for all non-hydrogen atoms was performed after the data have been corrected for absorption effects. All calculations were performed with the SHELX program, and the data were processed with the programs X-Red and X-Shape. ${ }^{17}$ After the refinement of the structure $[\mathrm{HNMP}]_{2}\left\{\mathrm{Mn}(\mathrm{B} 4 \mathrm{~S})(\mathrm{NMP})_{2}\right\}$, a large electron density remained which could be attributed to the disorder of the $[\mathrm{HNMP}]^{+}$cation and the $\mathrm{SO}_{3}$ groups of the benzenetetrasulfonate anions. The disorder was well resolved using split positions for the respective molecules leading to an occupancy ratio of $6: 4$ for the $\mathrm{SO}_{3}$ groups of the $\mathrm{B}_{4} \mathrm{~S}^{4-}$ anions and $7: 3$ for the $[\mathrm{HNMP}]^{+}$cation and gave an $R_{1}=0.0387$.
Also in the compound $\mathrm{Mn}(\mathrm{BDS})(\mathrm{DMA})_{2}$, a disorder of the solvent molecule occurs. The DMA molecule with the numbering $\mathrm{O} 2 / \mathrm{C} 21 / \mathrm{C} 22 / \mathrm{N} 2 / \mathrm{C} 23 / \mathrm{C} 24$ has two arrangements. The disorder was well resolved using split positions for the DMA molecules leading to an occupancy ratio of $7.5: 2.5$ and gave an $R_{1}=0.0348$. Tables 4 and 5 give details of the data collection and the obtained crystallographic data. In Tables 6 and 7 , important distances are summarized.

\section{Thermal analysis}

The investigation of the thermal behavior was performed using a TGA/DSC apparatus (Mettler-Toledo $\mathrm{GmbH}$, Schwerzenbach, Switzerland). In a flow of dry oxygen, about $5 \mathrm{mg}$ of the respective compound were placed in a corundum crucible and heated at a rate of $10 \mathrm{~K} \mathrm{~min}^{-1}$ up to $1050{ }^{\circ} \mathrm{C}$. The collected data were processed using the software of the analyzer
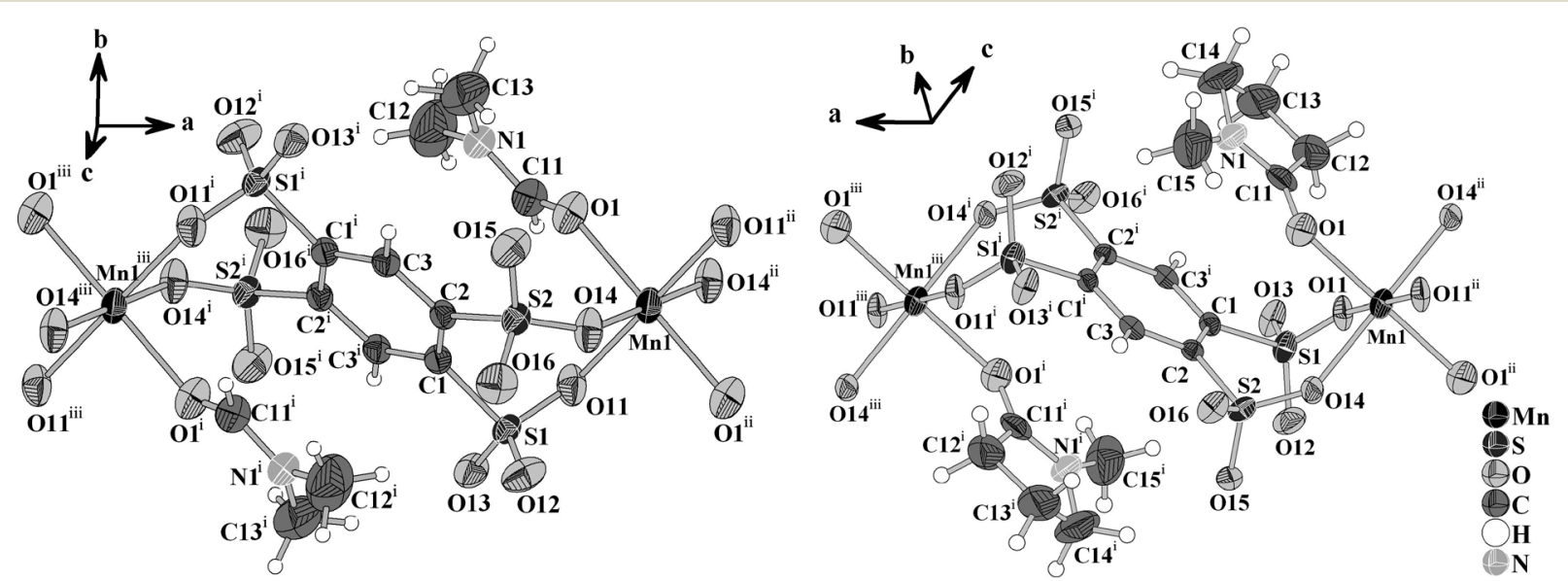

Fig. 2 Sections of the anionic chains $\left\{\mathrm{Mn}(\mathrm{B} 4 \mathrm{~S})(\mathrm{L})_{2}\right\}^{2-}(\mathrm{L}=\mathrm{DMF}, \mathrm{NMP})$ in I (left) and II (right). The Mn atoms and the centroids of the benzene ring are located on special crystallographic sites bearing inversion symmetry. The displacement ellipsoids are drawn at a $50 \%$ probability level. Symmetry codes: I: (i) $=-x,-y,-z$; (ii) $=1-x,-y,-z$; (iii) $=-1+x, y, z$; I: (i) $=-x,-1-y,-1-z$; (ii) $=-1-x,-1-y,-1-z$; (iii) $=1+x, y, z$.

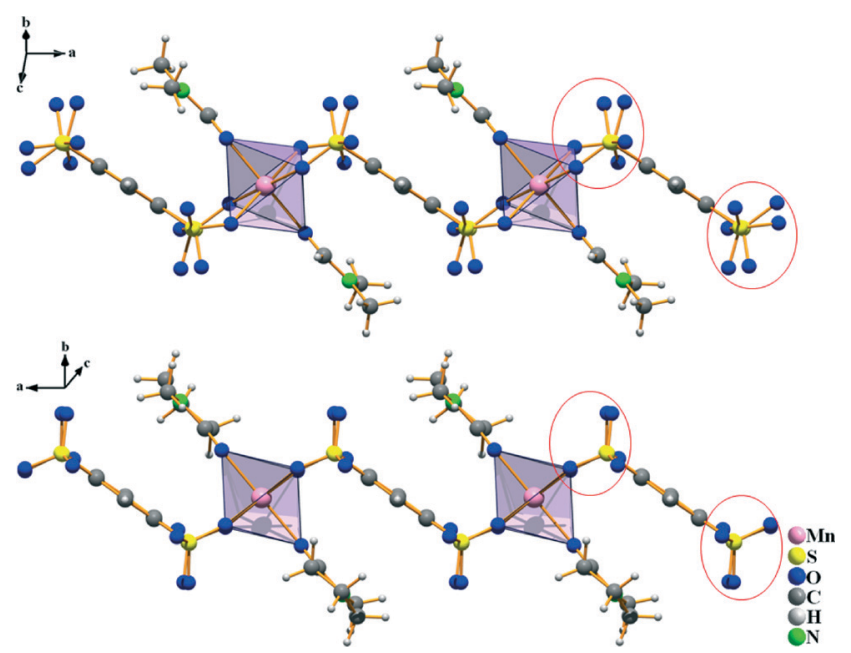

Fig. 3 A closer look on the anionic chains in I (top) and II (bottom) shows the differences between the compounds. When viewed along the S...S direction of neighboring $\left[\mathrm{SO}_{3}\right]$ groups, the oxygen atoms are either in a staggered (I) or an eclipsed (II) conformation (as emphasized by the red circles). 


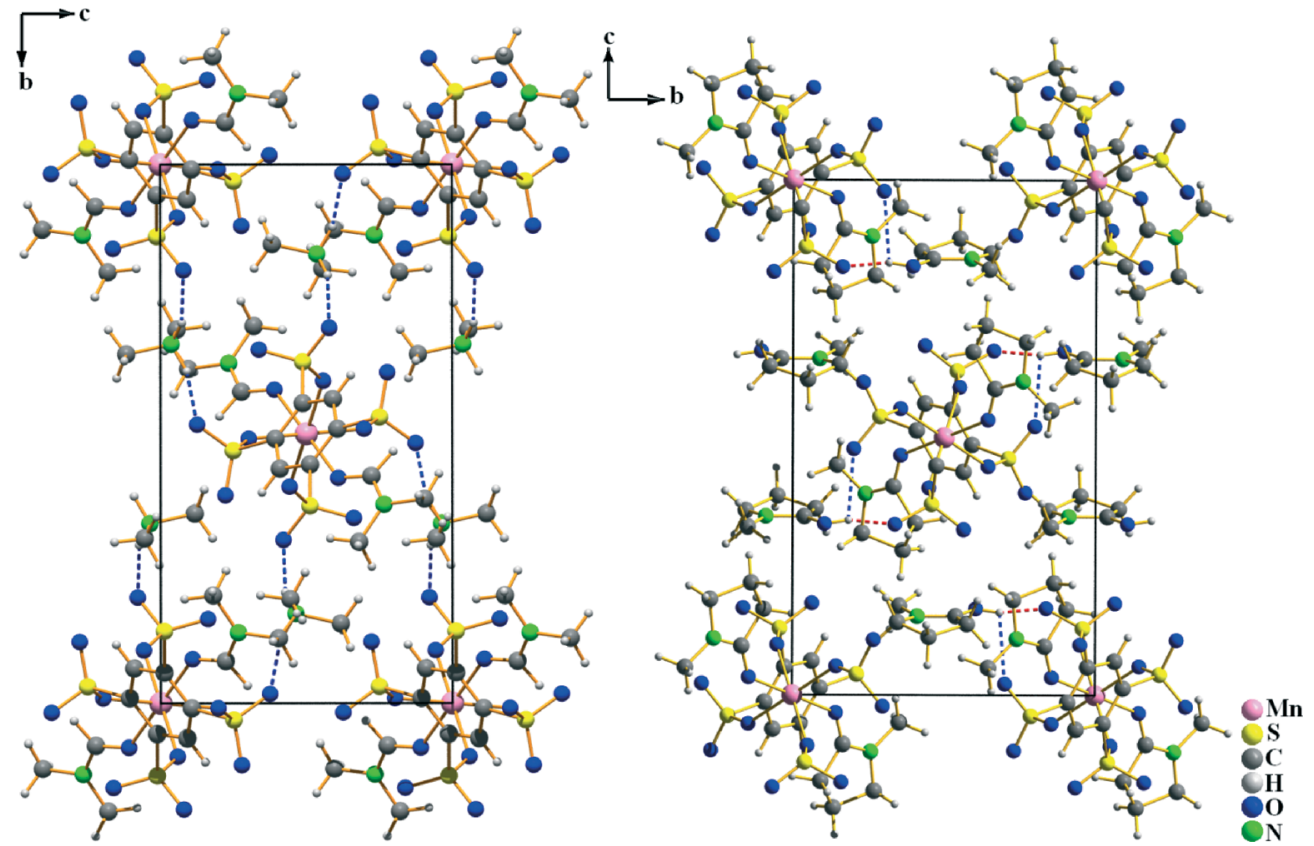

Fig. 4 Crystal structures of I (left) and II (right) viewed along the [100] direction of the monoclinic unit cells. In this direction, the anionic chains shown in Fig. 3 are oriented. The charge compensation is achieved by $\left[\mathrm{NH}_{2}\left(\mathrm{CH}_{3}\right)_{2}\right]^{+}$and $[\mathrm{HNMP}]^{+}$cations which also show hydrogen bonding to neighboring oxygen atoms of $\left[\mathrm{SO}_{3}\right]$ groups. These are emphasized as dashed lines in red (strong $\mathrm{H}$-bonds) and blue (medium strong $\mathrm{H}$-bonds).

(Mettler-Toledo STARe V9.3). ${ }^{18}$ Thermal decomposition data for $\left[\mathrm{NH}_{2}\left(\mathrm{CH}_{3}\right)_{2}\right]_{2}\left\{\mathrm{Mn}(\mathrm{B} 4 \mathrm{~S})(\mathrm{DMF})_{2}\right\},[\mathrm{HNMP}]_{2}\left\{\mathrm{Mn}(\mathrm{B} 4 \mathrm{~S})(\mathrm{NMP})_{2}\right\}$, $\mathrm{Mn}(\mathrm{BDS})(\mathrm{DMF})_{2}, \mathrm{Mn}(\mathrm{BDS})(\mathrm{DMA})_{2}$ and $\mathrm{Mn}(\mathrm{BDS})(\mathrm{NMP})_{2}$ are presented in Tables 2 and 3 and Fig. 8 and 10.

\section{Powder diffraction}

XRD measurements were measured with the help of the powder diffractometer STADIP using $\mathrm{Cu}-\mathrm{K} \alpha$ radiation $(\lambda=154.06 \mathrm{pm})$. The compounds under investigation were prepared on a flat sample holder. The diffraction data were processed with the WinXPow 2007 program package. ${ }^{19}$

\section{Magnetic property measurements}

The magnetic property measurements were carried out using a Quantum Design Physical Property Measurement System using a vibrating sample magnetometer. The measurement was performed in the temperature range of 3-300 $\mathrm{K}$ with flux densities up to $80 \mathrm{kOe}$. $15.569 \mathrm{mg}$ of the polycrystalline sample was packed in a polypropylene capsule and fixed to a brass sample holder rod.

\section{Results and discussion}

\section{Crystal structures}

Benzenetetrasulfonates. The crystal structures of $\left[\mathrm{NH}_{2}\left(\mathrm{CH}_{3}\right)_{2}\right]_{2}\left\{\mathrm{Mn}(\mathrm{B} 4 \mathrm{~S})(\mathrm{DMF})_{2}\right\}(\mathrm{I})$ and $[\mathrm{HNMP}]_{2}\left\{\mathrm{Mn}(\mathrm{B} 4 \mathrm{~S})(\mathrm{NMP})_{2}\right\}$ (II) exhibit anionic chains according to ${ }_{\infty}^{1}\left\{\mathrm{Mn}(\mathrm{B} 4 \mathrm{~S})_{2 / 2}(\mathrm{~L})_{2}\right\}^{2-}$ ( $\mathrm{L}=\mathrm{DMF}$, NMP). Within the chains, both the $\mathrm{Mn}^{2+}$ ions and the centroids of the benzene rings of the anions are located on special crystallographic positions with -1 site symmetry
(Wyckoff sites $2 b$ and $2 a$ ). The $\mathrm{Mn}^{2+}$ ions are coordinated by two bidentate $\mathrm{B}_{4} \mathrm{~S}^{4^{-}}$ligands and two solvent molecules (Fig. 2). The resulting $\left[\mathrm{MnO}_{6}\right]$ octahedra are quite regular and display distances $\mathrm{Mn}-\mathrm{O}$ of 217.1(2), 215.4(2) and 216.4(2) pm for compound $\mathbf{I}$. The longest bond is found for the coordinating DMF molecules, and the shorter ones are found for the B4 $\mathrm{S}^{4-}$ ligands. In II, the situation is opposite and the shortest distance Mn-O of 215.7(2) pm is that to the NMP molecule, while the sulfonate ligands shows slightly larger values of 218.3(3) and 219.1(4) pm, respectively. Another significant difference in the anionic chains of both compounds is the orientation of the $\left[\mathrm{SO}_{3}\right]$ moieties of the tetrasulfonates with respect to each other. When viewed along the $\mathrm{S} \cdots \mathrm{S}$ direction of neighboring $\left[\mathrm{SO}_{3}\right]$ groups, it is obvious that the oxygen atoms have a staggered conformation in I and an eclipsed one in II (Fig. 3).

The ${ }_{\infty}^{1}\left\{\mathrm{Mn}(\mathrm{B} 4 \mathrm{~S})(\mathrm{L})_{2}\right\}^{2-}$ chains in both compounds are aligned along the [100] direction (Fig. 4). They are arranged in densest rod packing fashion and their charge is compensated by dimethylammonium cations (in I) and by protonated

Table 1 Hydrogen bonds in $\left[\mathrm{NH}_{2}\left(\mathrm{CH}_{3}\right)_{2}\right]_{2}\left\{\mathrm{Mn}(\mathrm{B} 4 \mathrm{~S})(\mathrm{DMF})_{2}\right\}$ (I) and $[\mathrm{HNMP}]_{2}\left\{\mathrm{Mn}(\mathrm{B} 4 \mathrm{~S})(\mathrm{NMP})_{2}\right\}$ (II) with $\mathrm{d}(\mathrm{H} \cdots \mathrm{A})<r(\mathrm{~A})+200 \mathrm{pm}$ and $\angle \mathrm{DHA}>$ $110 \mathrm{deg}$. The strong hydrogen bonds are marked in bold ${ }^{a}$

\begin{tabular}{|c|c|c|c|c|c|c|}
\hline & D-H & $\mathrm{d}(\mathrm{D}-\mathrm{H}) / \mathrm{pm}$ & $\mathrm{d}(\mathrm{H} \cdots \mathrm{A}) / \mathrm{pm}$ & $\angle \mathrm{DHA} /^{\circ}$ & $\mathrm{d}(\mathrm{D} \cdots \mathrm{A}) / \mathrm{pm}$ & A \\
\hline \multirow[t]{2}{*}{ I } & $\mathrm{N} 2-\mathrm{H} 21$ & $93(4)$ & $202(4)$ & $160(3)$ & $291.5(3)$ & $013^{i}$ \\
\hline & $\mathrm{N} 2-\mathrm{H} 22$ & $100(4)$ & $190(4)$ & $155(3)$ & 283.1(3) & O16 \\
\hline \multirow[t]{2}{*}{ II } & $\mathrm{O} 2-\mathrm{H} 1$ & $85.0(1)$ & $175(4)$ & $136(5)$ & $243.3(4)$ & $\mathrm{O15}^{\mathrm{ii}}$ \\
\hline & $\mathrm{O} 2-\mathrm{H} 1$ & $85.0(1)$ & $237(5)$ & $115(4)$ & 283.8(5) & $\mathrm{O} 12^{\mathrm{ii}}$ \\
\hline
\end{tabular}


NMP molecules (in II), respectively. The $\left[\mathrm{NH}_{2}\left(\mathrm{CH}_{3}\right)_{2}\right]^{+}$originate obviously from the partial decomposition of the DMF solvent. The protonation of the NMP molecule can be easily identified by inspection of the $\mathrm{C}-\mathrm{O}$ distance. It is found at
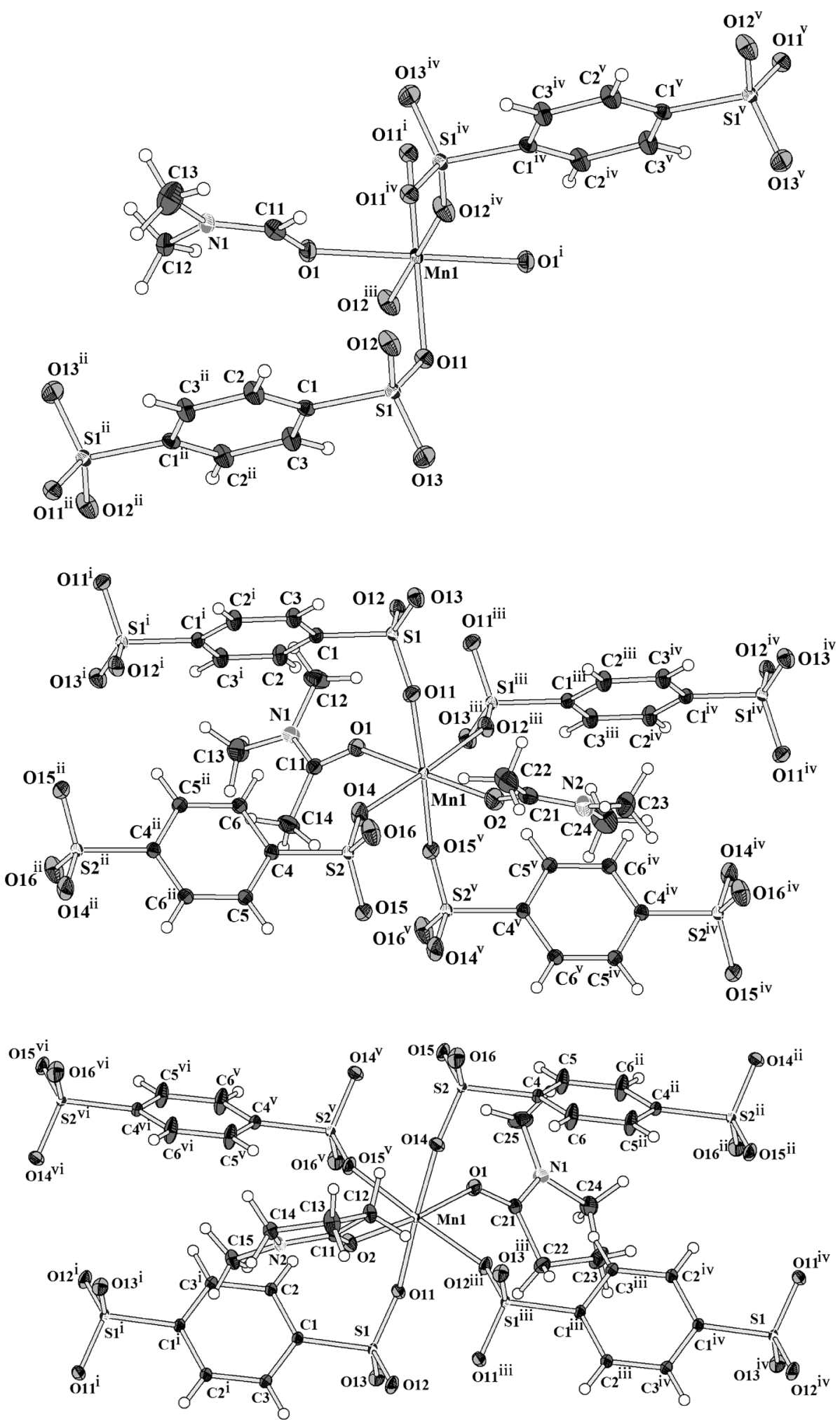

Fig. 5 Coordination of the $\mathrm{Mn}^{2+}$ ions in $\mathrm{Mn}(\mathrm{BDS})(\mathrm{DMF})_{2}$ (III, top), $\mathrm{Mn}(\mathrm{BDS})(\mathrm{DMA})_{2}$ (IV, middle), and $\mathrm{Mn}(\mathrm{BDS})(\mathrm{NMP})_{2}(\mathrm{~V}$, bottom). Note that in the structure of III the manganese site show inversion symmetry. The displacement ellipsoids are drawn at a $50 \%$ probability level. For compounds IV and $\mathrm{V}$, the asymmetric unit has two half $\mathrm{BDS}^{2-}$ moieties, each lying at independent inversion centres. Symmetry codes: III: (i) $=-x, 1-y, 1-z ;$ (ii) $=1-x$, $2-y, 1-z$; (iii) $=-1+x, y, z$; (iv) $=1-x, 1-y, 1-z$; (v) $=x,-1+y, z$; IV: (i) $=1-x, 1-y, 1-z$; (ii) $=1-x, 1-y, 2-z$; (iii) $=1-x,-y, 1-z$; (iv) $=x,-1+y$, $z ;(\mathrm{v})=1-x,-y, 2-z ; \mathrm{V}$ : (i) $=-x,-y, 2-z ;$ (ii) $=2-x,-y, 1-z ;$ (iii) $=1-x,-y, 2-z$; (iv) $=1+x, y, z ;(\mathrm{v})=1-x,-y, 1-z ;(\mathrm{vi})=-1+x, y, z$. 

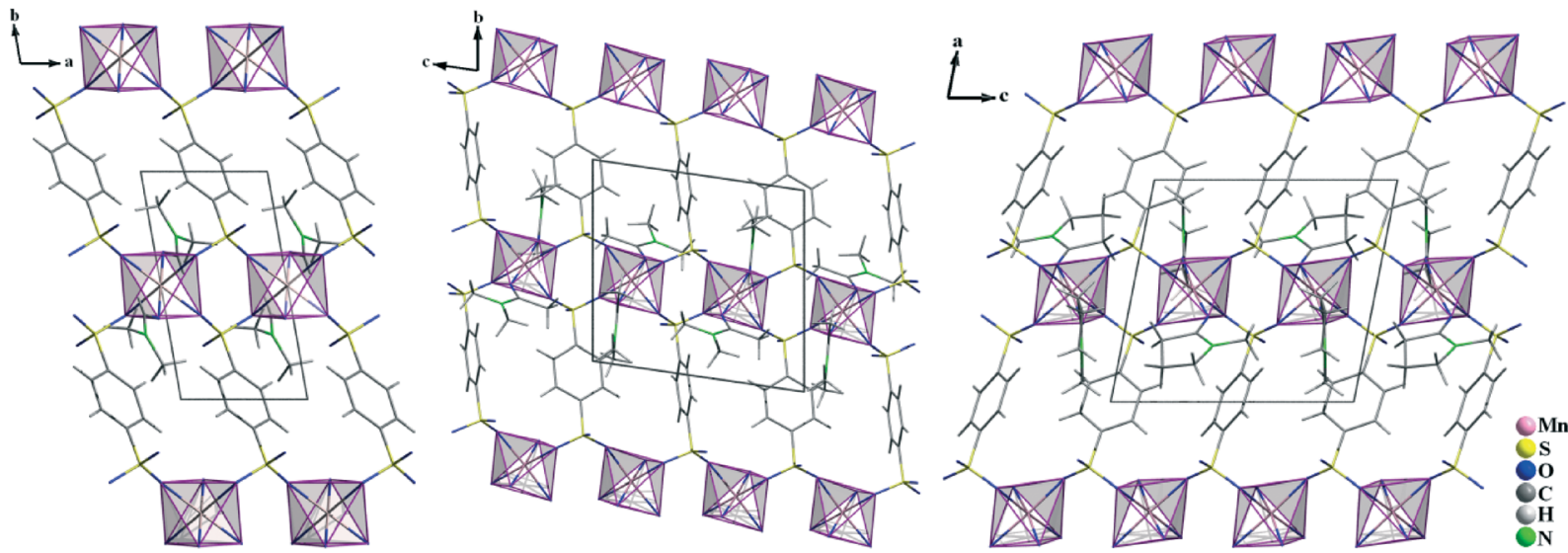

Fig. 6 Crystal structures of $M n(B D S)(D M F)_{2}$ (III, left), $M n(B D S)(D M A)_{2}$ (IV, middle) and $M n(B D S)(N M P)_{2}(V$, right). For all structures, the view is onto the ${ }_{\infty}^{2}\left\{\mathrm{Mn}(\mathrm{BDS})_{4 / 2}(\mathrm{~L})_{2 / 1}\right\}$ layers. The structures differ due to the different orientation of the $\mathrm{BDS}^{2-}$ anions with respect to each other.
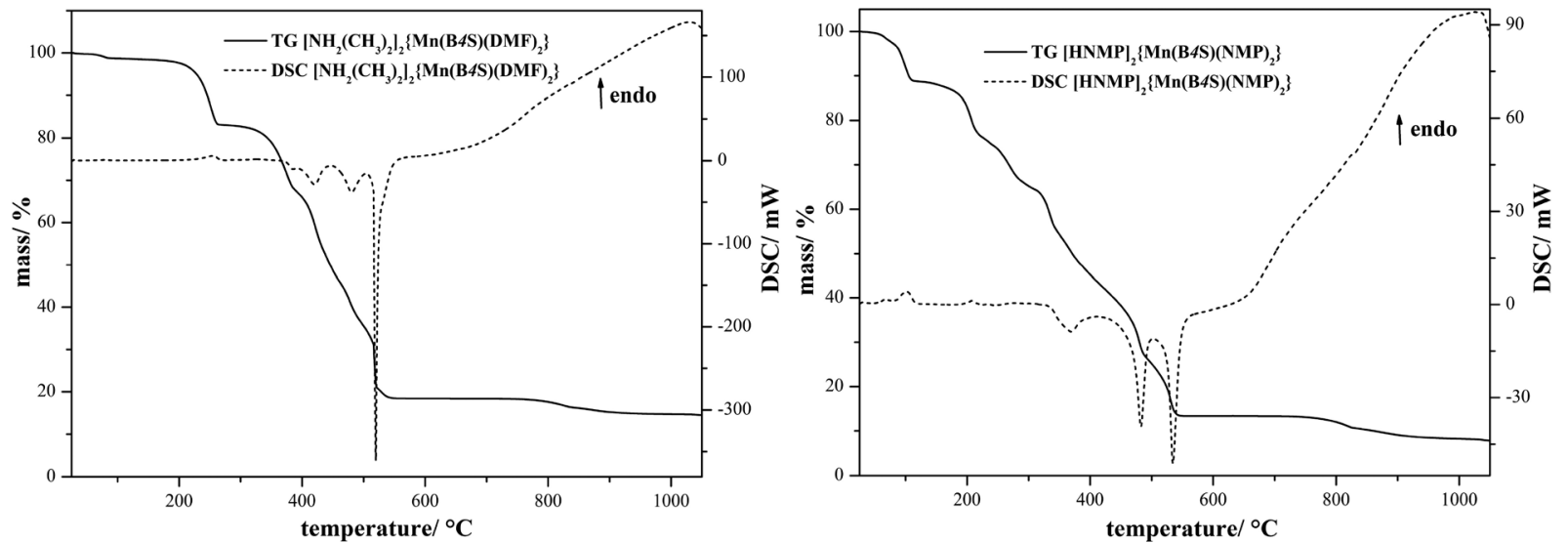

Fig. 7 DSC/TG diagrams of the thermal decompositions of $\left[\mathrm{NH}_{2}\left(\mathrm{CH}_{3}\right)_{2}\right]_{2}\left\{\mathrm{Mn}(\mathrm{B} 4 \mathrm{~S})(\mathrm{DMF})_{2}\right\}$ (I) and $[\mathrm{HNMP}]_{2}\left\{\mathrm{Mn}(\mathrm{B} 4 \mathrm{~S})(\mathrm{NMP})_{2}\right\}$ (II). The decompositions are composed of endothermic steps which can be attributed to the loss of solvent molecules and decompositions of the cations $\left[\mathrm{NH}_{2}\left(\mathrm{CH}_{3}\right)_{2}\right]^{+}$and $[\mathrm{HNMP}]^{+}$, respectively. Subsequently, the intermediate product, most probably $\mathrm{Mn}\left(\mathrm{H}_{2} \mathrm{~B} 4 \mathrm{~S}\right)$, decomposes in various exothermic steps, leading finally to $\mathrm{Mn}_{2} \mathrm{O}_{3}$ and $\mathrm{Mn}_{3} \mathrm{O}_{4}$.

Table 2 Thermal decomposition data of the anionic chain compounds I and II

\begin{tabular}{|c|c|c|c|c|c|c|}
\hline Stage & $T_{\text {onset }} /{ }^{\circ} \mathrm{C}$ & $T_{\text {end }} /{ }^{\circ} \mathrm{C}$ & $T_{\max } /{ }^{\circ} \mathrm{C}$ & Mass loss obsd./\% & Mass loss calcd./\% & Elimination/decomposition \\
\hline 1 & 40 & 85 & 79 & 2 & \multirow[t]{2}{*}{33} & \multirow{2}{*}{$\begin{array}{l}\text { Loss of two equiv. of } \mathrm{NH}\left(\mathrm{CH}_{3}\right)_{2} \text { and two } \\
\text { equiv. of DMF }\end{array}$} \\
\hline 3 & 326 & 392 & 375 & 16 & & \\
\hline 4 & 392 & 442 & 420 & 21 & \multirow[t]{3}{*}{ - } & \multirow{3}{*}{$\begin{array}{l}\text { Decomposition to } \mathrm{Mn}_{3} \mathrm{O}_{4} \text { and } \mathrm{MnSO}_{4} \\
\text { and } \mathrm{MnO}_{2}\end{array}$} \\
\hline 5 & 455 & 512 & 480 & 10 & & \\
\hline 6 & 512 & 550 & 520 & 18 & & \\
\hline$\sum$ & & & & 86 & 89 & $\begin{array}{l}\text { Decomposition to } \mathrm{Mn}_{2} \mathrm{O}_{3} \text { and } 4 \mathrm{Mn}_{3} \mathrm{O}_{4} \\
\text { (calcd. } 11 \% \text { ) }\end{array}$ \\
\hline \multicolumn{7}{|c|}{$[\mathrm{HNMP}]_{2}\left\{\mathrm{Mn}(\mathrm{B} 4 \mathrm{~S})(\mathrm{NMP})_{2}\right\}(\mathrm{II})$} \\
\hline 1 & 51 & 108 & $65 ; 100$ & 11 & 23 & \multirow[t]{2}{*}{ Loss of two equiv. of NMP } \\
\hline 2 & 185 & 225 & 208 & 13 & & \\
\hline 3 & 225 & 300 & $235 ; 268$ & 12 & 23 & Loss of two equiv. of NMP \\
\hline 8 & 720 & 830 & 826 & 5 & - & \multirow{2}{*}{$\begin{array}{l}\text { Decomposition to } \mathrm{Mn}_{2} \mathrm{O}_{3} \text { and } \mathrm{Mn}_{3} \mathrm{O}_{4} \\
\text { (calcd. } 9 \% \text { ) }\end{array}$} \\
\hline$\sum$ & & & & 92 & 91 & \\
\hline
\end{tabular}


128.5(6) pm for the [HNMP $]^{+}$ion, while the respective distance is $123.7(3) \mathrm{pm}$ in the manganese coordinated NMP molecule. Furthermore, the proton can be found in the Fourier map during the crystal structure refinement, even if it was refined by a constrained model. For both of the different cations, hydrogen bonds to the non-coordinating oxygen atoms of the $\left[\mathrm{SO}_{3}\right]$ group could be identified. In I, the donor-acceptor distances D-A are found at 283.1(3) and $291.5(3) \mathrm{pm}$ and the angles $\angle \mathrm{DHA}$ are $155(3)^{\circ}$ and $160(3)^{\circ}$, hinting at medium-strong hydrogen bonds. ${ }^{20}$ In compound II, the hydrogen bonds with donor-acceptor distances of 243.3(4) and 283.8(5) pm with the respective angles $\angle$ DHA being $136(5)^{\circ}$ and $115(4)^{\circ}$ ( $c f$. Table 1 ) are quite strong. ${ }^{20}$ The observed hydrogen bonds are emphasized in Fig. 4 .

Benzenedisulfonates. The manganese benzenedisulfonates $\mathrm{Mn}(\mathrm{BDS})(\mathrm{DMF})_{2}$ (III), $\mathrm{Mn}(\mathrm{BDS})(\mathrm{DMA})_{2}$ (IV), and $\mathrm{Mn}(\mathrm{BDS})(\mathrm{NMP})_{2}$ (V) crystallize with triclinic symmetry. The structures are similar in the way that the $\mathrm{Mn}^{2+}$ ions are octahedrally coordinated by oxygen atoms that belong to four disulfonate ligands and two solvent molecules (Fig. 5). The solvent molecules are in trans orientation with respect to each other at the apices of the $\left[\mathrm{MnO}_{6}\right]$ octahedra. In III, the $\left[\mathrm{MnO}_{6}\right]$ octahedron bears inversion symmetry, i.e. the $\mathrm{Mn}^{2+}$ ion is located on a special site of the triclinic unit cell (Wyckoff position $1 g$ ). In IV and $\mathbf{V}$, the manganese atoms are situated on general sites (Wyckoff position 2i). In all of the three compounds, the distances $\mathrm{Mn}-\mathrm{O}$ lie in a narrow range between 213 and $219 \mathrm{pm}$ (Table 7).

In all of the three compounds, the $\mathrm{Mn}^{2+}$ ions are linked by the benzenedisulfonate ligands to layers according to $\infty^{2}\left\{\mathrm{Mn}(\mathrm{BDS})_{4 / 2}(\mathrm{~L})_{2 / 1}\right\}$ (L = DMF, DMA, NMP) (Fig. 6). The structural differences arise from the arrangement of the $\mathrm{BDS}^{2-}$ anions with respect to each other in the individual structures. In III, the benzenedisulfonate anions have the same orientation, while in IV and $\mathbf{V}$, the single $\mathrm{BDS}^{2-}$ anions are twisted with respect to each other (Fig. 6). The solvent molecules $\mathrm{L}$ point into the interlayer spacing, and weak interactions to the non-coordinating oxygen atoms of the $\left[\mathrm{SO}_{3}\right]$ moieties of adjacent layers can be assumed.

\section{Thermal behaviour}

Thermal decomposition of $I$ and II. The thermal decomposition of $\left[\mathrm{NH}_{2}\left(\mathrm{CH}_{3}\right)_{2}\right]_{2}\left\{\mathrm{Mn}(\mathrm{B} 4 \mathrm{~S})(\mathrm{DMF})_{2}\right\}$ (I) and $[\mathrm{HNMP}]_{2}\left\{\mathrm{Mn}(\mathrm{B} 4 \mathrm{~S})(\mathrm{NMP})_{2}\right\}$ (II) was monitored by means of DSC/TG measurements in a flow of dry oxygen (Fig. 7 and Table 2). Both compounds decompose in multi-step processes; however, these steps are not clearly resolved in any
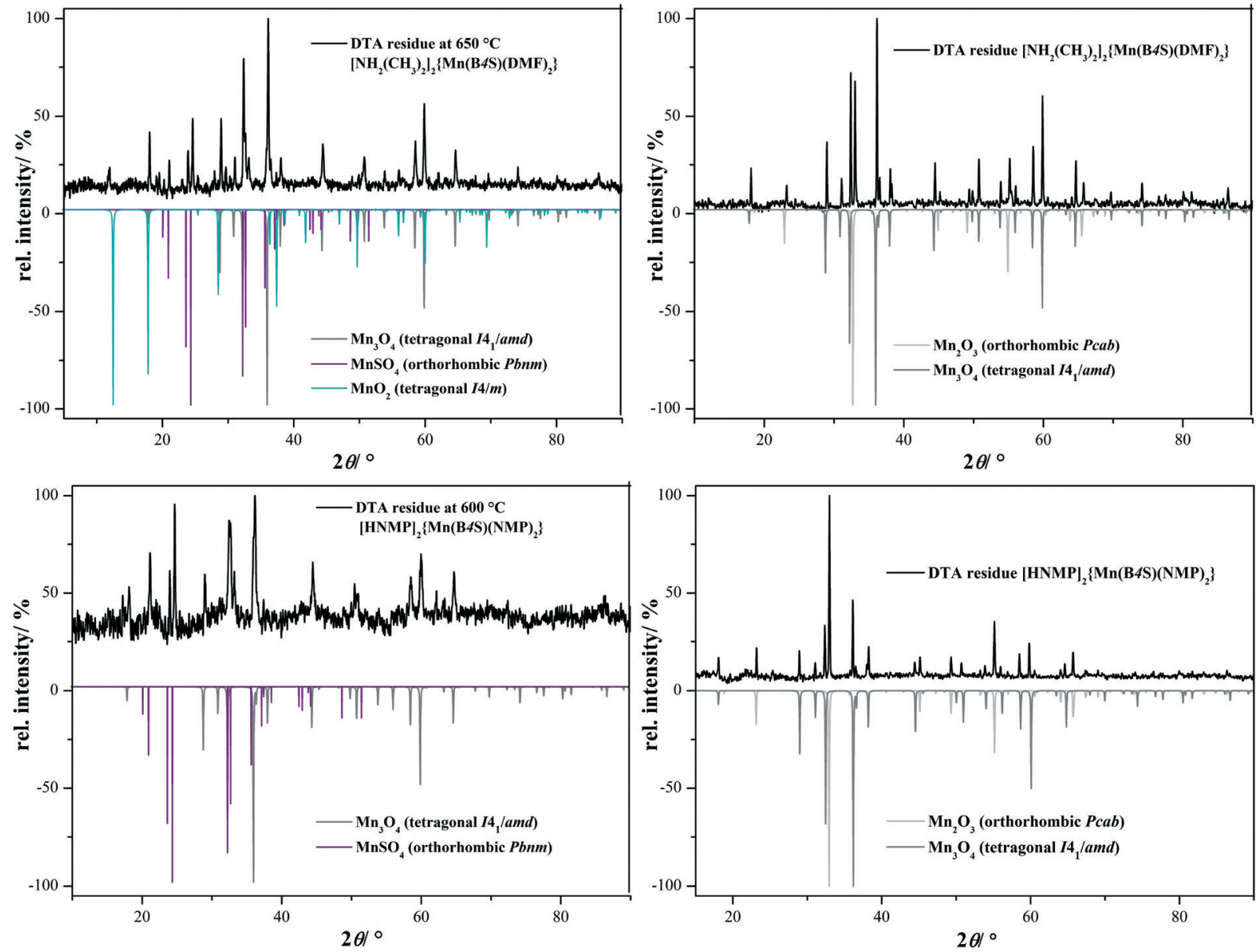

Fig. 8 Powder patterns of the intermediates (left) and final decomposition products (right) of I (top) and II (bottom). 
case. Nevertheless, it seems clear that the first endothermic steps can be attributed to the loss of the two solvent molecules and the decomposition of the cations under release of $\mathrm{NHMe}_{2}$ for compound I and NMP for compound II, respectively. This is in good accordance with the observed mass loss of $33 \%$ (calcd. $33 \%$ ) for I and $47 \%$ (calcd. $46 \%$ ) for II (cf. Table 2). In both cases, this should lead formally to the formation of the dihydrogentetrasulfonate " $\mathrm{Mn}\left(\mathrm{H}_{2} \mathrm{~B} 4 \mathrm{~S}\right)$ ", which subsequently decomposes in the course of three exothermic steps. According to XRD investigations at $650{ }^{\circ} \mathrm{C}$ (compound I) and $600{ }^{\circ} \mathrm{C}$ (compound $\mathrm{II}$ ), respectively, the decomposition leads to a mixture of $\mathrm{MnSO}_{4}$ and $\mathrm{Mn}_{3} \mathrm{O}_{4}$ (Fig. 8). ${ }^{21,22}$ For I, small amounts of $\mathrm{MnO}_{2}$ are also observed in the diffraction pattern. ${ }^{23}$ In a final step, the manganese(II)sulfate
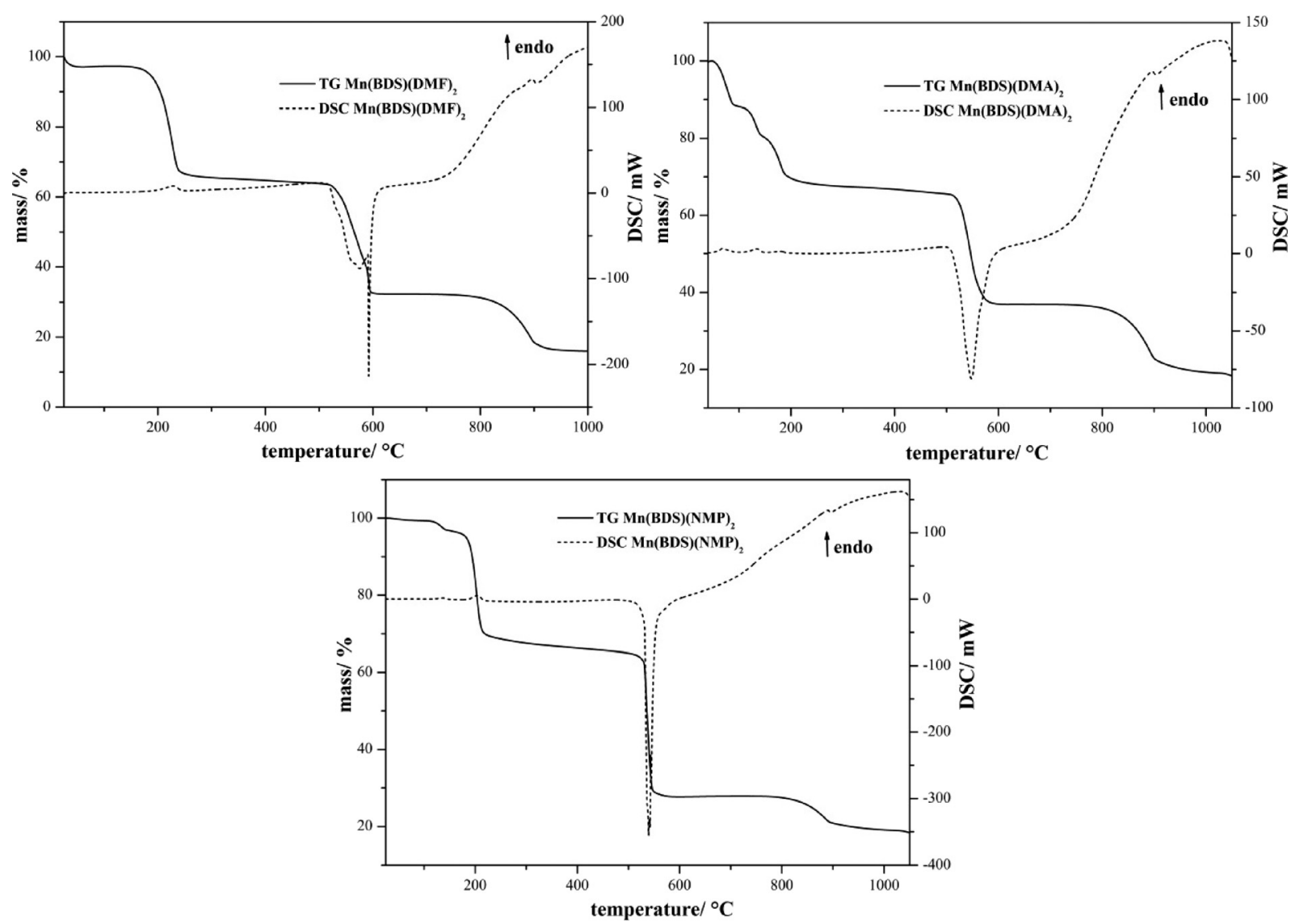

Fig. 9 TG/DSC diagram of the thermal decomposition of $\mathrm{Mn}(\mathrm{BDS})(\mathrm{DMF})_{2}$ (III), $\mathrm{Mn}(\mathrm{BDS})(\mathrm{DMA})_{2}$ (IV), and Mn(BDS)(NMP) 2 (V). The decomposition of all compounds starts with the loss of the solvent molecules. Finally, the solvent-free compounds decompose exothermally at temperatures above $500^{\circ} \mathrm{C}$.

Table 3 Thermal decomposition data of the benzenedisulfonates III, IV, and V

\begin{tabular}{|c|c|c|c|c|c|c|}
\hline \multicolumn{7}{|c|}{$\mathrm{Mn}(\mathrm{BDS})(\mathrm{DMF})_{2}(\mathrm{III})$} \\
\hline I & 190 & 245 & 230 & 34 & 33 & Loss of two equiv. of DMF \\
\hline III & 860 & 906 & 895 & 17 & 17 & Decomposition to $\mathrm{Mn}_{3} \mathrm{O}_{4}$ (calcd. $17 \%$ ) \\
\hline$\sum$ & & & & 84 & 82 & \\
\hline III & 775 & 896 & 890 & 9 & - & Decomposition to $\mathrm{Mn}_{2} \mathrm{O}_{3}$ and $9 \mathrm{Mn}_{3} \mathrm{O}_{4}$ (calcd. $16 \%$ ) \\
\hline$\sum$ & & & & 82 & 84 & \\
\hline \multicolumn{7}{|c|}{$\operatorname{Mn}(\mathrm{BDS})(\mathrm{DMA})_{2}(\mathrm{~V})$} \\
\hline I & 50 & 195 & $68 ; 135 ; 180$ & 34 & 37 & Loss of two equiv. of DMA \\
\hline II & 508 & 593 & 547 & 31 & - & Decomposition to $\mathrm{Mn}_{3} \mathrm{O}_{4}$ and $\mathrm{MnSO}_{4}$ \\
\hline
\end{tabular}


decomposes to $\mathrm{Mn}_{2} \mathrm{O}_{3}$ according to the XRD pattern of the final residue. ${ }^{24}$

Thermal decomposition of III, IV, and V. The thermal decomposition of compounds III, IV, and $\mathbf{V}$ was investigated by DSC/TG measurements in a flow of dry oxygen (Fig. 9 and Table 3). All of the compounds decompose in three-step processes. The first steps are endothermic and can be attributed to the loss of the solvent molecules. The solvent-free manganese benzenedisulfonates $\mathrm{Mn}(\mathrm{BDS})$ show high thermal stabilities, and the decompositions start clearly above $500{ }^{\circ} \mathrm{C}$. These decompositions lead in a first step to $\mathrm{MnSO}_{4}$ (for IV, a small amount of $\mathrm{Mn}_{3} \mathrm{O}_{4}$ is also seen, $c f$. Fig. 10). ${ }^{22,23,26}$ The anhydrous manganese sulfate occurs in two different modifications, as can be seen from XRD measurements of the decomposition products obtained at $650{ }^{\circ} \mathrm{C}$ (Fig. 10). As a result of the preparation of the sample on a flat sample holder, reflections of the hydrate $\mathrm{Mn}\left(\mathrm{SO}_{4}\right) \cdot 2 \mathrm{H}_{2} \mathrm{O}$ might also occur. $^{27}$ In any case, the manganese sulfate decomposes
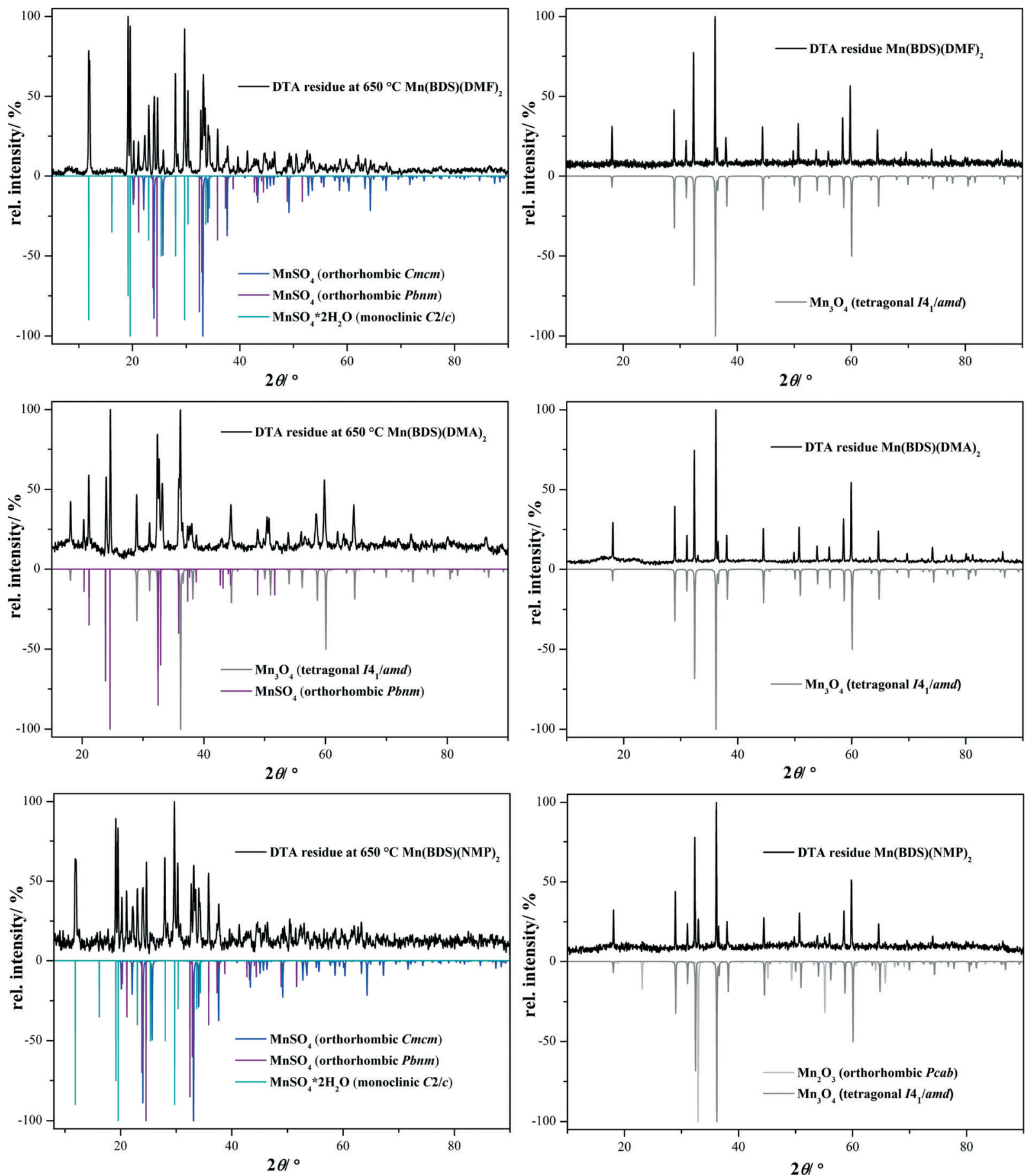

Fig. 10 Powder patterns of the intermediate (left) and final product (right) of III (top), IV (middle) and V (bottom). 
further leading essentially to $\mathrm{Mn}_{3} \mathrm{O}_{4}$, although in the case of compound II $\mathrm{Mn}_{2} \mathrm{O}_{3}$ is also found as a minor decomposition product (Fig. 10). ${ }^{23,25}$ The quantification of the crystalline phases contained in powder samples of the final product was estimated with respect to the reflection intensities as determined by Rietveld refinements. ${ }^{28}$

\section{Magnetic properties of $\left[\mathrm{NH}_{2}\left(\mathrm{CH}_{3}\right)_{2}\right]_{2}\left\{\mathrm{Mn}(\mathrm{B} 4 \mathrm{~S})(\mathrm{DMF})_{2}\right\}$}

The temperature-dependent magnetic susceptibility and inverse magnetic susceptibility data $\left(\chi\right.$ and $\left.\chi^{-1}\right)$ are depicted in Fig. 11 (top). The inverse magnetic susceptibility shows linear variation with temperature, indicating Curie-Weiss behavior $\left[\chi=C /\left(T-\theta_{\mathrm{P}}\right)\right]$ over the whole temperature range. $\mathrm{A}$ fit of the data set resulted in an effective magnetic moment of 5.19(1) $\mu_{\mathrm{B}} / \mathrm{Mn}$ atom and a Weiss constant of $\theta_{\mathrm{P}}=-1.9(5) \mathrm{K}$, indicating minute antiferromagnetic interactions in the paramagnetic domain. The effective magnetic moment is in between the values for a $\mathrm{Mn}^{2+}$ (h.s.) ion $\left(\mu_{\text {theo }}=5.92 \mu_{\mathrm{B}}\right)$ and a $\mathrm{Mn}^{3+}$ (h.s.) ion $\left(\mu_{\text {theo }}=4.90 \mu_{\mathrm{B}}\right) .{ }^{29}$ From crystal chemical considerations, a $\mathrm{Mn}^{2+}$ ion in high spin configuration is to be expected.

The 100 Oe measurement in zero-field-cooled/field-cooled mode (inset of Fig. 11, center) reveals a trace amount of ferromagnetic impurity at $T_{\mathrm{C}}=32.5(5) \mathrm{K}$. This is consistent with the ferromagnetic ordering temperature of $\mathrm{MnCO}_{3}$ $\left(T_{\mathrm{C}}=32.2 \mathrm{~K}\right) .{ }^{30}$ The ZFC/FC measurement was repeated with a magnetic flux density of 500 Oe in order to saturate the ferromagnetic $\mathrm{MnCO}_{3}$ impurity (Fig. 11, center) to show the extrinsic nature of this anomaly. The $\mathrm{MnCO}_{3}$ impurity obviously remains from the synthesis which starts from $\mathrm{MnCO}_{3}$ as the manganese source.

Fig. 11 (bottom) shows the magnetization isotherms of the $\left[\mathrm{NH}_{2}\left(\mathrm{CH}_{3}\right)_{2}\right]_{2}\left\{\mathrm{Mn}(\mathrm{B} 4 \mathrm{~S})(\mathrm{DMF})_{2}\right\}$ sample measured at 5, 10, 25 and $50 \mathrm{~K}$ with magnetic flux densities up to $80 \mathrm{kOe}$. The $5 \mathrm{~K}$ isotherm exhibits pronounced curvature without showing any indication of a magnetic ordering phenomenon, the curvature of the $10 \mathrm{~K}$ isotherm is less pronounced and the 25 and $50 \mathrm{~K}$ isotherms show linear dependence of temperature as is expected for a paramagnetic material.

Taking the trace amount of $\mathrm{MnCO}_{3}$ into account, one can assume that the compound contains $\mathrm{Mn}^{2+}$ ions in high spin configuration. No magnetic ordering phenomenon was evident within the investigated temperature range.

\section{Conclusion}

In the course of our investigations on the preparation of novel polysulfonic acids and their use in the synthesis of polysulfonates, we have obtained five manganese polysulfonates based on the acids $\mathrm{H}_{4} \mathrm{~B} 4 \mathrm{~S}$ (1,2,4,5-benzenetetrasulfonic acid) and $\mathrm{H}_{2}$ BDS (1,4-benzenedisulfonic acid). The compounds were prepared by solvothermal reactions at elevated temperatures. While the tetrasulfonates exhibit unique anionic chains according to ${ }_{\infty}^{1}\left\{\mathrm{Mn}(\mathrm{B} 4 \mathrm{~S})_{2 / 2}(\mathrm{~L})_{2}\right\}^{2-}(\mathrm{L}=\mathrm{DMF}, \mathrm{NMP})$, the disulfonates show layer-type structures. For both kinds of compound, thermoanalytical measurements show that
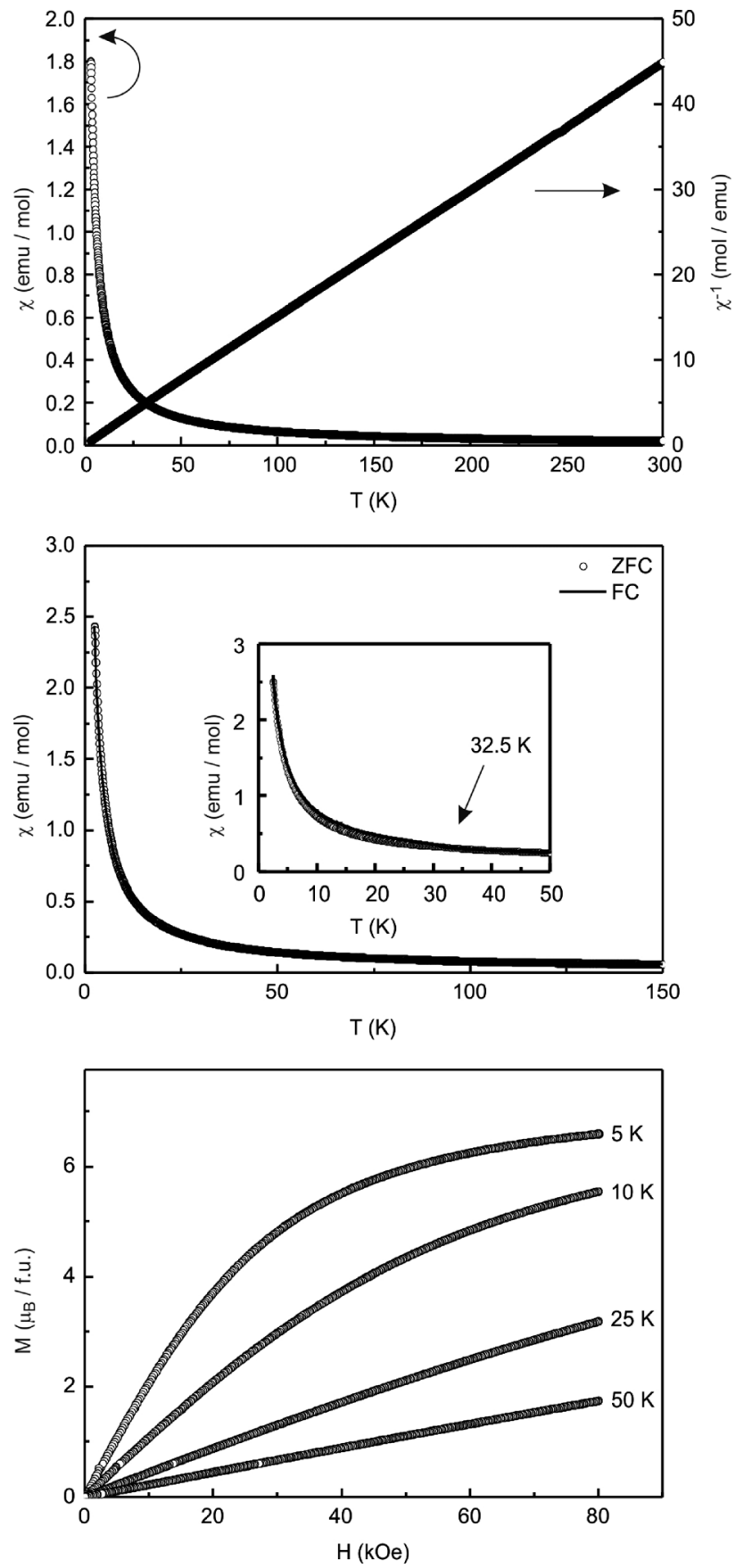

Fig. 11 Magnetic behavior of $\left[\mathrm{NH}_{2}\left(\mathrm{CH}_{3}\right)_{2}\right]_{2}\left\{\mathrm{Mn}(\mathrm{B} 4 \mathrm{~S})(\mathrm{DMF})_{2}\right\}$. The temperature-dependent magnetic susceptibility and inverse magnetic susceptibility (upper part) reveal the paramagnetic behaviour of the compound. In zero-field-cooled/field-cooled measurement mode (middle), a small amount of ferromagnetic impurity $\left(\mathrm{MnCO}_{3}\right)$ can be identified. The magnetization isotherms (bottom) gave no hint of a magnetic ordering phenomenon.

the sulfonates have exceptionally high decomposition temperatures, especially when compared to related polycarboxylates. ${ }^{31}$ Further investigations shall now elucidate the structures of the solvent-free compounds in order to investigate if they are porous MOF-type materials. The final decomposition products are $\mathrm{Mn}_{3} \mathrm{O}_{4}$ and $\mathrm{Mn}_{2} \mathrm{O}_{3}$. For the chain-type 
Table 4 Crystallographic data of $\left[\mathrm{NH}_{2}\left(\mathrm{CH}_{3}\right)_{2}\right]_{2}\left\{\mathrm{Mn}(\mathrm{B} 4 \mathrm{~S})(\mathrm{DMF})_{2}\right\}$ and $[\mathrm{HNMP}]_{2}\left\{\mathrm{Mn}(\mathrm{B} 4 \mathrm{~S})(\mathrm{NMP})_{2}\right\}$ and their determination

\begin{tabular}{|c|c|c|}
\hline & {$\left[\mathrm{NH}_{2}\left(\mathrm{CH}_{3}\right)_{2}\right]_{2}\left\{\mathrm{Mn}(\mathrm{B} 4 \mathrm{~S})(\mathrm{DMF})_{2}\right\}$} & {$[\mathrm{HNMP}]_{2}\left\{\mathrm{Mn}(\mathrm{B} 4 \mathrm{~S})(\mathrm{NMP})_{2}\right\}$} \\
\hline Density (calculated $\mathrm{g} \mathrm{cm}^{-3}$ ) & 1.58 & 1.62 \\
\hline Cell volume & $1444.4(1) \AA^{3}$ & $1743.1(2) \AA^{3}$ \\
\hline No. of formula units & 2 & 2 \\
\hline Measuring device & Stoe IPDS I & Bruker APEX II \\
\hline Radiation & Mo-K $\alpha, \lambda=71.07$ pm & Mo-K $\alpha, \lambda=71.07 \mathrm{pm}$ \\
\hline Temp. & $296 \mathrm{~K}$ & $120 \mathrm{~K}$ \\
\hline Absorption correction & Numerical & Numerical \\
\hline$\mu$ & $8.2 \mathrm{~cm}^{-1}$ & $7.0 \mathrm{~cm}^{-1}$ \\
\hline Measured reflections & 22160 & 77638 \\
\hline$R_{1} ; \mathrm{w} R_{2}\left(I_{\mathrm{o}}>2 \sigma\left(I_{\mathrm{o}}\right)\right)$ & $0.0357 ; 0.0771$ & $0.0501 ; 0.1310$ \\
\hline$R_{1} ; \mathrm{w} R_{2}$ (all data) & $0.0643 ; 0.0837$ & $0.0818 ; 0.1484$ \\
\hline Max./min. electron density & $0.62 /-0.26 \mathrm{e} / \AA^{3}$ & $1.10 /-0.47 \mathrm{e} / \AA^{3}$ \\
\hline CCDC number & 951310 & 959360 \\
\hline
\end{tabular}

Table 5 Crystallographic data of $\mathrm{Mn}(\mathrm{BDS})(\mathrm{DMF})_{2}, \mathrm{Mn}(\mathrm{BDS})(\mathrm{DMA})_{2}$, and $\mathrm{Mn}(\mathrm{BDS})(\mathrm{NMP})_{2}$

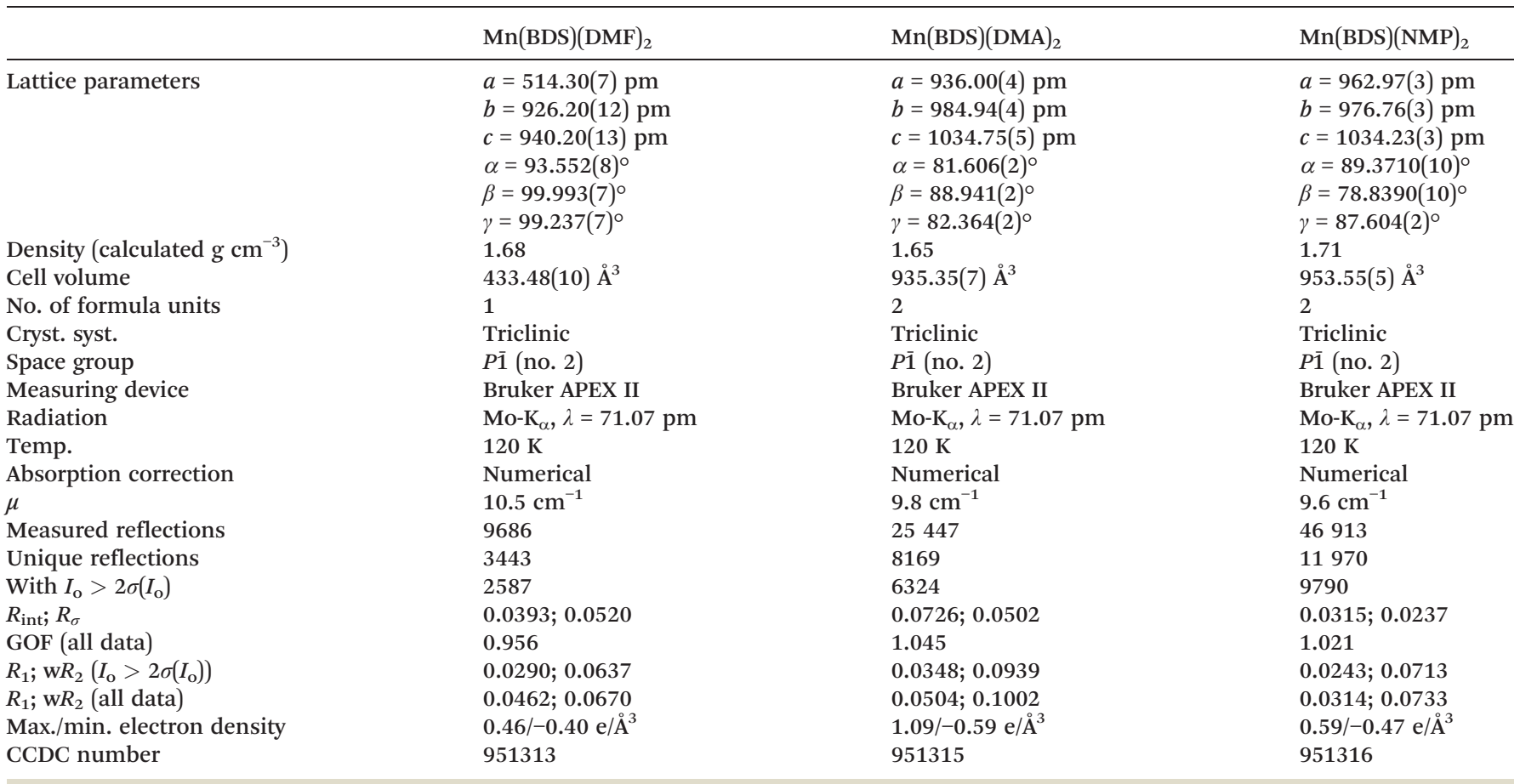

tetrasulfonate $\left[\mathrm{NH}_{2}\left(\mathrm{CH}_{3}\right)_{2}\right]_{2}\left\{\mathrm{Mn}(\mathrm{B} 4 \mathrm{~S})(\mathrm{DMF})_{2}\right\}$, magneto chemical investigations have also been performed, proving the ferromagnetic behavior of the compound. Magnetic coupling, however, is not observed. The results presented show that polysulfonates are a highly interesting class of compounds that need further investigation. The fundament for these investigations is the development of preparative routes for polysulfonic acids, and thus, the strength of this project is the combination of expertise from organic chemistry and that from inorganic chemistry.

\section{Acknowledgements}

The authors thank Dipl.-Chem. Wolfgang Saak and Dr. Marc Schmidtmann for the collection of the X-ray data and Florian Behler for the measurements of the IR spectra. 
Table 6 Selected distances (pm) and angles (deg.) for $\left[\mathrm{NH}_{2}\left(\mathrm{CH}_{3}\right)_{2}\right]_{2}\left\{\mathrm{Mn}(\mathrm{B} 4 \mathrm{~S})(\mathrm{DMF})_{2}\right\}$ and $[\mathrm{HNMP}]_{2}\left\{\mathrm{Mn}(\mathrm{B} 4 \mathrm{~S})(\mathrm{NMP})_{2}\right\}$

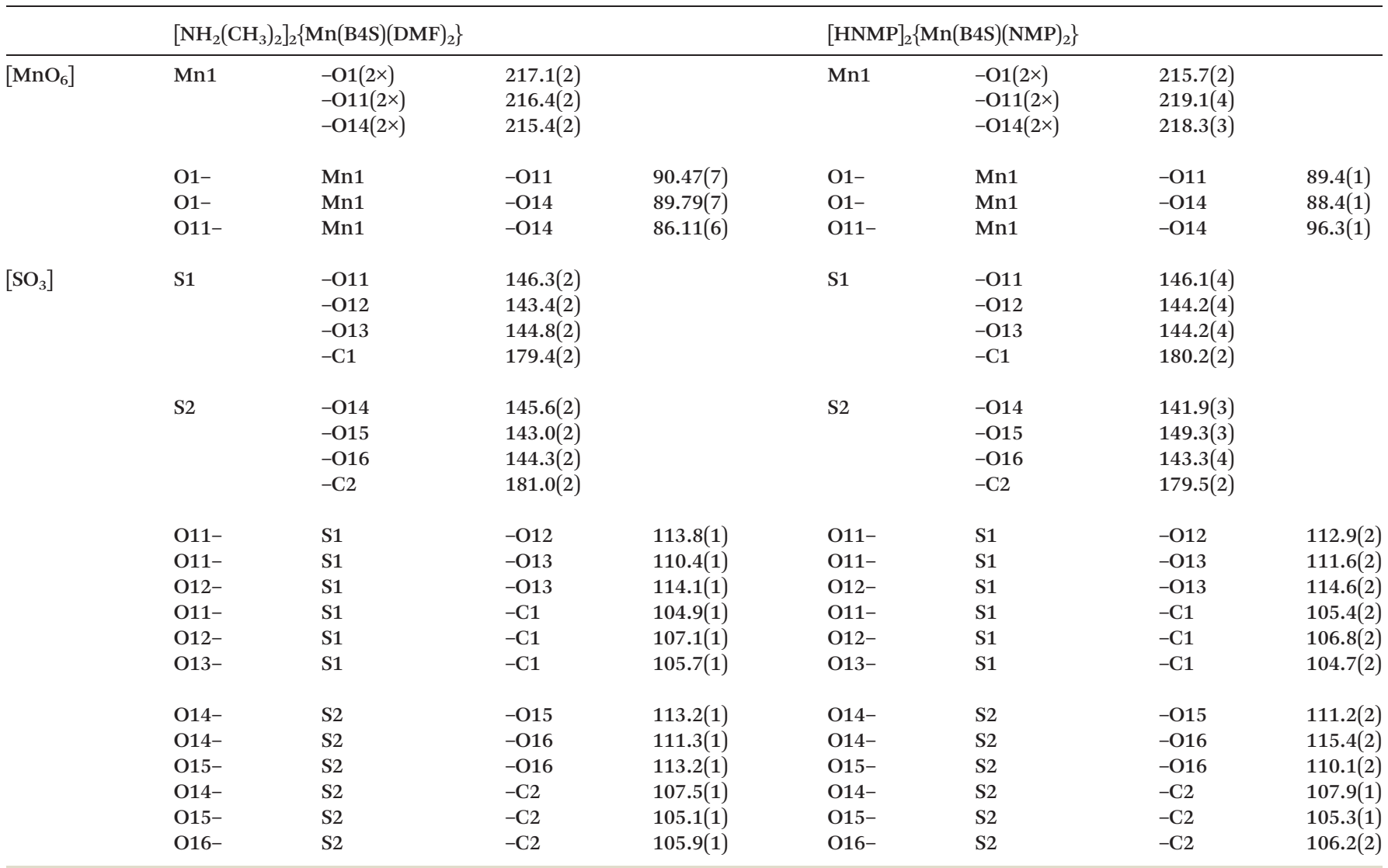

Financial support by the Deutsche Forschungsgemeinschaft is also gratefully acknowledged.

\section{References}

1 (a) C. Janiak, Dalton Trans., 2003, 2781-2804; (b) A. K. Cheetham, C. N. R. Rao and R. K. Feller, Chem. Commun., 2006, 4780-4795.

2 C. Janiak and J. K. Vieth, New J. Chem., 2010, 34, 2366-2388.

3 (a) H. Li, M. Eddaoudi, M. O'Keeffe and O. M. Yaghi, Nature, 1999, 402, 276-279; (b) U. Mueller, M. Schubert, F. Teich, H. Puetter, K. Schierle-Arndt and J. Pastre, J. Mater. Chem., 2006, 16, 626-636; (c) S. Bauer and N. Stock, Chem. Unserer Zeit, 2008, 42, 12-19.

4 (a) J.-M. Shi, W. Xu, Q.-Y. Liu, F.-L. Liu, Z.-L. Huang, H. Lei, W.-T. Yu and Q. Fang, Chem. Commun., 2002, 756-757; (b) G.-F. Liu, Z.-P. Qiao, H.-Z. Wang, X.-M. Chen and G. Yang, New J. Chem., 2002, 26, 791-795; (c) T. M. Reineke, M. Eddaoudi, M. Fehr, D. Kelley and O. M. Yaghi, J. Am. Chem. Soc., 1999, 121, 1651-1657; (d) Y. Zhu, Z. Sun, Y. Zhao, J. Zhang, X. Lu, N. Zhang, L. Liu and F. Tong, New J. Chem., 2009, 33, 119-124; (e) N. Kerbellec, L. Catala, C. Daiguebonne, A. Gloter, O. Stephan, J.-C. Bünzli, O. Guillou and T. Mallah, New J. Chem., 2008, 32, 584-587; $(f)$ X. Yang, J. H. Rivers, W. J. McCarty, M. Wiester and R. A. Jones, New J. Chem., 2008, 32, 790-793.
5 M. D. Allendorf, C. A. Bauer, R. K. Bhakta and R. J. T. Houk, Chem. Soc. Rev., 2009, 38, 1330-1352.

6 (a) J. A. Real, E. Andres, M. C. Munoz, M. Julve, T. Granier, A. Bousseksou and F. Varret, Science, 1995, 268, 265-267; (b) L. G. Beauvais, M. P. Shores and J. R. Long, J. Am. Chem. Soc., 2000, 122, 2763-2772.

7 (a) H. A. Habib, J. Sanchiz and C. Janiak, Dalton Trans., 2008, 1734-1744; (b) D. Maspoch, D. Ruiz-Molina and J. Veciana, Chem. Soc. Rev., 2007, 36, 770-818; (c) M. Kurmoo, Chem. Soc. Rev., 2009, 38, 1353-1379; (d) J. Larionova, Y. Guari, C. Sangregorio and C. Guérin, New J. Chem., 2009, 33, 1177-1190.

8 (a) L. J. Murray, M. Dincǎ and J. R. Long, Chem. Soc. Rev., 2009, 38, 1294-1314; (b) J. L. C. Rowsell and O. M. Yaghi, Angew. Chem., Int. Ed., 2005, 44, 4670-4679; (c) J.-R. Li, R. J. Kuppler and H.-C. Zhou, Chem. Soc. Rev., 2009, 38, 1477-1504; (d) C.-J. Li, Z.-J. Lin, M.-X. Peng, J.-D. Leng, M.-M. Yang and M.-L. Tong, Chem. Commun., 2008, 6348-6350; (e) S. S. Iremonger, P. D. Southon and C. J. Kepert, Dalton Trans., 2008, 6103-6105; $(f)$ S. Ma, D. Sun, M. Ambrogio, J. A. Fillinger, S. Parkin and H. C. Zhou, J. Am. Chem. Soc., 2007, 129, 1858-1859; $(g)$ S. Ma and H.-C. Zhou, Chem. Commun., 2010, 46, 44-53.

9 Z. Hulvey, E. H. L. Falcao, J. Echert and A. K. Cheetham, J. Mater. Chem., 2009, 19, 4307-4309.

10 (a) S. Kitagawa, R. Kitaura and S. Noro, Angew. Chem., 2004, 116, 2388-2430; (b) G. Férey, Chem. Mater., 2001, 13, 
Table 7 Selected distances (pm) and angles (deg.) for $\mathrm{Mn}(\mathrm{BDS})(\mathrm{DMF})_{2}, \mathrm{Mn}(\mathrm{BDS})(\mathrm{DMA})_{2}$, and $\mathrm{Mn}(\mathrm{BDS})(\mathrm{NMP})_{2}$

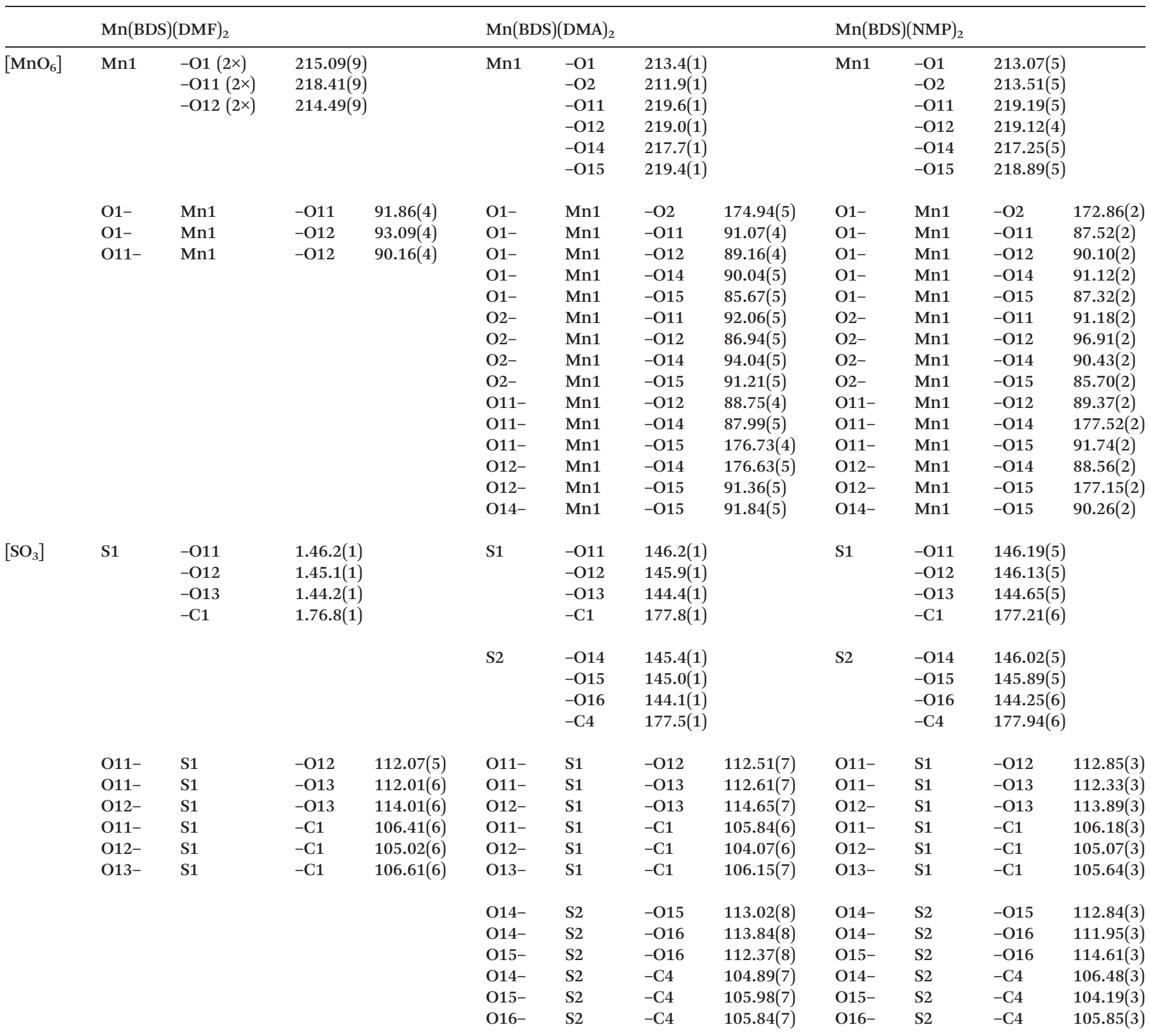

3084-3098; (c) J. L. C. Rowsell and O. M. Yaghi, Microporous Mesoporous Mater., 2004, 73, 3-14.

11 (a) B. D. Chandler, G. D. Enright, K. A. Udachin, S. Pawsey, J. A. Ripmeester, D. T. Cramb and G. K. H. Shimizu, Nat. Mater., 2008, 7, 229-235; (b) G. K. H. Shimizu, R. Vaidhyanathan and J. M. Taylor, Chem. Soc. Rev., 2009, 38, 1430-1449; (c) G. B. Deacon, A. Gitlits, G. Zelesny, D. Stellfeldt and G. Meyer, Z. Anorg. Allg. Chem., 1999, 625, 764-772; (d) G. B. Deacon, R. Harika, P. C. Junk, B. W. Skelton and A. H. White, New J. Chem., 2007, 31, 634-645; (e) D. J. Hoffart, S. A. Dalrymple and G. K. H. Shimizu, Inorg. Chem., 2005, 44, 8868-8875; $(f)$ V. Videnova-Adrabinska, Coord. Chem. Rev., 2007, 251, 1987-2016.
12 (a) K. T. Holman, A. M. Pivovar, J. A. Swift and M. D. Ward, Acc. Chem. Res., 2001, 34, 107-118; (b) K. T. Holman, S. M. Martin, D. P. Parker and M. D. Ward, J. Am. Chem. Soc., 2001, 123, 4421-4431; (c) M. J. Horner, K. T. Holman and M. D. Ward, J. Am. Chem. Soc., 2007, 129, 14640-14660; (d) V. A. Russell, C. C. Evans, W. Li and M. D. Ward, Science, 1997, 276, 575-579; (e) J. A. Swift, A. M. Pivovar and A. M. Reynolds, J. Am. Chem. Soc., 1998, 24, 5887-5894; $(f)$ J. A. Swift, A. M. Reynolds and M. D. Ward, Chem. Mater., 1998, 10, 4159-4168.

13 A. Mietrach, T. W. T. Muesmann, J. Christoffers and M. S. Wickleder, Eur. J. Inorg. Chem., 2009, 5328-5334.

14 T. W. T. Muesmann, A. Mietrach, J. Christoffers and M. S. Wickleder, Z. Anorg. Allg. Chem., 2010, 636, 1307-1312. 
15 (a) A. Mietrach, T. W. T. Muesmann, C. Zilinski, J. Christoffers and M. S. Wickleder, Z. Anorg. Allg. Chem., 2011, 637, 195-200; (b) T. W. T. Muesmann, C. Zitzer, A. Mietrach, T. Klüner, J. Christoffers and M. S. Wickleder, Dalton Trans., 2011, 40, 3128-3141; (c) T. W. T. Muesmann, C. Zitzer, M. S. Wickleder and J. Christoffers, Inorg. Chim. Acta, 2011, 369, 45-48.

16 BrukerOptik GmbH, OPUS 6.5, Germany, 2009.

17 (a) G. M. Sheldrick, Acta Crystallogr., Sect. A: Found. Crystallogr., 2008, 64, 112-122; (b) X-RED 1.22, Stoe \& Cie, Darmstadt, Germany, 2001; (c) X-SHAPE 1.06f, Stoe \& Cie, Darmstadt, Germany, 1999.

$18 \operatorname{Star}^{e} V$ 9.3, Mettler-Toledo GmbH, Schwerzenbach, Switzerland, 2009.

19 WinXPOW 2007, Stoe \& Cie, Darmstadt, Germany, 2006.

20 G. A. Jeffrey, An Introduction to Hydrogen Bonding, Oxford University Press, New York, 1997.

21 O. V. Dolomanov, L. J. Bourhis, R. J. Gildea, J. A. K. Howard and H. Puschmann, OLEX2, J. Appl. Crystallogr., 2009, 42, 339-341.

22 A. Kirfel and G. Will, High Temp. - High Pressures, 1974, 6, 525-527.
23 G. Aminoff, Z. Kristallogr., Kristallgeom., Kristallphys., Kristallchem., 1927, 64, 475-490.

24 Y. D. Kondrashev, A. I. Zaslavskii, Golden Book of Phase Transitions, Wroclaw, 2002, vol. 1, 1-123.

25 S. Geller, Acta Crystallogr., Sect. B: Struct. Crystallogr. Cryst. Chem., 1971, 27, 821-828.

26 G. Will, Acta Crystallogr., 1965, 19, 854-857.

27 F. Golinska, A. Lodzinska and F. Rozploch, Pol. J. Chem., 1984, 58, 31-39.

28 High Score Plus V 3.0d, PANalytical B. V., Almelo, Netherlands, 2011.

29 H. Lueken, Magnetochemie, B.G. Teubner, Stuttgart, 1999.

30 (a) I. Maartense, Phys. Rev., 1969, 188, 924-930; (b) A. Kosterov, T. Frederichs and T. von Dobeneck, Phys. Earth Planet. Inter., 2006, 154, 234-242.

31 (a) L.-F. Song, C.-H. Jiang, C.-L. Jiao, J. Zhang, L.-X. Sun, F. Xu, Q.-Z. Jiao, Y.-H. Xing, Y. Du, Z. Cao and F.-L. Huang, J. Therm. Anal. Calorim., 2010, 102, 1161-1166; (b) R.-Q. Zhong, R.-Q. Zou, M. Du, T. Yamada, G. Maruta, S. Takeda, J. Li and Q. Xu, CrystEngComm, 2010, 12, 677-681; (c) Y. Liu, H. Li, Y. Han, X. Lv, H. Hou and Y. Fan, Cryst. Growth Des., 2012, 12, 3505-3513. 